\title{
Unusual mitochondrial genome in introduced and native populations of Listronotus bonariensis (Kuschel)
}

\author{
C. LENNEY WILLIAMS $\uparrow$, S. L. GOLDSON $\$$ \& D. W. BULLOCK* \\ Centre for Molecular Biology, PO Box 84, Lincoln University, Canterbury and $\ddagger$ AgResearch, PO Box 60, Lincoln, New \\ Zealand
}

\begin{abstract}
The Argentine stem weevil is a serious pest of pasture and other graminaceous crops in New Zealand. Fifteen populations from South America, New Zealand and Australia were examined in an effort to determine the geographical origin of the species in New Zealand. Our previously reported RAPD analysis of these populations (Williams et al., 1994) revealed that the source of the pest was the Rio de la Plata on the east coast of South America. As a second approach to examining genetic variation, RFLP analysis of the mitochondrial genome, using the digoxigenin-labelled boll weevil mitochondrial genome as a probe, was also performed. The mitochondrial analysis revealed that the species possesses an unusually large mitochondrial genome of $32 \mathrm{~kb}$, which exhibits extremely low levels of polymorphism both in the introduced and native populations. This low variation is in contrast with the informative level of inter- and intrapopulation variation revealed by RAPD.
\end{abstract}

Keywords: genetic variation, introduced species, Listronotus bonariensis, mitochondrial genome, RFLP.

\section{Introduction}

The Argentine stem weevil is an introduced pest throughout New Zealand (Goldson \& Emberson, 1980 ) and causes $\$ N Z 78-251$ million in losses per annum, mainly through damaged pasture although the species also attacks other graminaceous crops (Prestidge et al., 1991). Our previous analysis of $L$. bonariensis (Williams et al., 1994) using RAPD (Williams et al., 1990; Welsh \& McClelland, 1990) was the first reported study of genetic variation in this species, and revealed informative levels of polymorphism. Based on the RAPD analysis of total DNA, the Rio de la Plata region on the east coast of South America was identified as the geographical source for this pest in New Zealand (Williams et al., 1994).

Mitochondrial (mt) DNA has also proven useful for elucidating the relationships within and between various populations and species (Wilson et al., 1985; Moritz et al., 1987). Wilson et al. (1985) reported

\footnotetext{
* Correspondence.

†Present Address: AgResearch, PO Box 60, Lincoln, New Zealand.
}

that the typical mitochondrial genome was about 15 kilobases (kb). Soon afterwards, sizes of 14-26 kb were found for animal mtDNA, owing to differences in copy number of short, tandemly repeated sequences within the control region or to duplication or deletion of sequences (Moritz et al., 1987). Boyce et al. (1989) reported an unusually large mitochondrial genome of $30-36 \mathrm{~kb}$ in bark weevils, attributed to the presence of varying numbers of a tandemly repeated region.

mtDNA typically follows maternal inheritance (Wilson et al., 1985) although the discovery of heteroplasmy in a wide range of organisms (Boyce $e t$ al., 1989; Rand \& Harrison, 1989; Kondo et al., 1990; Hoeh et al., 1991; Brown et al., 1992) suggests paternal 'leakage' of mtDNA can occur. Gyllensten et al. (1991) and Skibinski et al. (1994) presented further support for this hypothesis. Heteroplasmy appears to be the result of either biparental inheritance or mutation and still seems the exception rather than the rule, for most species.

mtDNA analysis has revealed vast amounts of information about intra- and interpopulation genetic diversity and gene flow (Avise et al., 1987). The approach has been instrumental in revealing diver- 
sity in such animals as grasshoppers (Chapco et al., 1992), deer mice (Lansman et al., 1983), island fox (Wayne et al., 1991) and rhinoceroses (O'Ryan \& Harley, 1993). Population data on insect pests other than Listronotus, such as the screwworm fly (Roehrdanz \& Johnson, 1988; Roehrdanz, 1989), boll weevil (Roehrdanz \& North, 1992) and mosquito (Kambhampati \& Rai, 1991), have been obtained using mtDNA analysis. High levels of mitochondrial polymorphism are not always detected (Baba-Aïssa et al., 1988; Kambhampati \& Rai, 1991), suggesting the occurrence of a bottleneck in the history of the species (Nigro, 1988).

Because of mtDNA's mode of inheritance (Wilson et al., 1985), mitochondrial lineages tend to become fixed within populations, although several haplotypes are commonly present within any given population. mtDNA analysis has revealed historic founding events in insects (Roehrdanz \& Johnson, 1988; Roehrdanz \& North, 1992), fish (Waldman \& Wirgin, 1994) and humans (Torrini et al., 1992). Mitochondrial restriction fragment length polymorphisms (mtRFLPs) have been used to trace colonization events in other insect pest species (Kambhampati \& Rai, 1991; Sheppard et al., 1992). As a corollary to our findings with total DNA, we thus examined the mtDNA of $L$. bonariensis. In this paper we present evidence that both introduced and native populations of this species have an unusually large mitochondrial genome that appears to be of a uniform haplotype.

\section{Materials and methods}

\section{Sample collection and storage}

Argentine stem weevil populations described previously (Williams et al., 1994) were used for this study. Adult individuals were collected from five populations within New Zealand (Lincoln, Ruakura, Reporoa, Wellsford, Gore), one population within Australia, and nine populations from South America (Buenos Aires, Bahia Blanca, Bariloche, Brazil, La Serena, Rio Negro, southern Chile, Uruguay, Mendoza). Samples were stored at $-80^{\circ} \mathrm{C}$.

\section{DNA isolation}

Total DNA was isolated from individuals as described previously (Williams et al., 1994) with the exception that the DNA was resuspended in $20 \mu \mathrm{L}$ TE (10 mм Tris, 1 mм EDTA, $\mathrm{pH} 8.0$ ) containing $0.5 \mathrm{mg} / \mathrm{mL}$ DNase-free RNase A.

\section{Restriction digests, electrophoresis and membrane} preparation

For each restriction digest, $4 \mu \mathrm{L}$ total DNA (equivalent to $1 / 5$ of the DNA of an individual) were digested with 5 units $(0.5 \mu \mathrm{L})$ of restriction enzyme in a total volume of $5 \mu \mathrm{L}$. Electrophoresis was in a 0.8 per cent LE Agarose gel (SeaKem) in $1 \times \mathrm{TBE}$ $(0.9 \mathrm{M}$ Tris-borate, $0.002 \mathrm{M}$ EDTA) at $60 \mathrm{~V}$ for $2 \mathrm{~h}$. The DNA was transferred onto nylon membrane by the method of Southern, as described in Sambrook et al. (1989).

\section{Probe preparation}

Plasmids pBW21, pBW22, pBW23 represent the entire boll weevil mitochondrial genome cloned as EcoRI fragments into pGEM-4Z (Roehrdanz \& North, 1992). After confirmation of identity by restriction mapping, insert DNA was excised with EcoRI and purified from a gel slice using a GlassMAX kit according to the manufacturer's instructions (Gibco BRL). Each EcoRI fragment was labelled separately with digoxigenin by random priming using a Boehringer Mannhein DIG DNA Labelling and Detection Kit. The efficiency of labelling was estimated according to the manufacturer's instructions (Boehringer Mannheim, 1993) and was consistently $5 \mathrm{ng}$ digoxiginin-labelled $\mathrm{DNA} / \mu \mathrm{L}$.

\section{Hybridization of probes to membranes}

Following the manufacturer's protocol, membranes were prehybridized at $65^{\circ} \mathrm{C}$ for $2 \mathrm{~h}$. Following 'mock' hybridizations to check the effect of probe concentration, $5 \mu \mathrm{L}$ labelling reaction $/ \mathrm{mL}$ hybridization solution (25 ng probe) was used. For the initial hybridizations to select useful restriction enzymes, membranes were probed with one or two of the labelled pBW fragments. These membranes indicated no variation between samples, so to generate the final data the entire boll weevil mitochondrial genome was used as the probe (all three fragments simultaneously) because this would allow quicker, more thorough screening than the use of the probes one at a time (the use of all three probes at $25 \mathrm{ng} / \mathrm{mL}$ each did not increase background signal). The membranes were hybridized at $65^{\circ} \mathrm{C}$ for $\approx 20 \mathrm{~h}$ using $3 \mathrm{~mL}$ probe solution. This probe solution was recovered the following day and frozen at $-20^{\circ} \mathrm{C}$ for future use. Each batch of probe solution was used three times before being discarded. The membranes were washed twice in $2 \times$ SSC $(1 \times$ SSC 
is $0.15 \mathrm{M} \mathrm{NaCl}, 0.015 \mathrm{M} \mathrm{Na}$ citrate), 0.1 per cent $(\mathrm{w} / \mathrm{v})$ sodium dodecyl sulphate (SDS) for $5 \mathrm{~min}$ at room temperature with shaking. The membranes were then washed twice in $0.1 \times \mathrm{SSC}, 0.1$ per cent (w/v) SDS for $15 \mathrm{~min}$ at $68^{\circ} \mathrm{C}$.

\section{Detection of membrane-bound probe}

Detection of the membrane-bound probe was according to the chemiluminescence protocol using the DIG DNA Labelling and Detection Kit (Boehringer Mannheim, 1993). After the incubation, the sealed membranes were exposed to a sheet of fast film (Kodak AXR) initially for $30 \mathrm{~min}$. Subsequent exposure times were adjusted as required. When necessary, membranes were stripped by boiling twice for $15 \mathrm{~min}$ in 0.1 per cent $(\mathrm{w} / \mathrm{v}) \mathrm{SDS}$, then rinsed twice for $1 \mathrm{~min}$ in $2 \times \mathrm{SSC}$.

\section{Determination of fragment size}

The mobilities of the detected fragments were measured from the autoradiograph and compared to size standards (1-kb ladder, Gibco BRL) by using the program SEQAID II (v3.5, Rhoads \& Roufa, University of Kansas, Manhattan, Kansas, U.S.A.) which computed fragment sizes by interpolation (Schaffer \& Sederoff, 1981).

\section{Results}

\section{Restriction enzyme selection}

Single samples of $L$. bonariensis DNA were digested with 25 different restriction enzymes, Aat I, Asp 700, Bam HI, BglII, Cla I, Eco RI, Eco RV, Hae III, HindIII, HinfI, Hpa I, Kpn I, Msp I, Nco I, Nhe I, Pst I, PvuI, Rsa I, SacI, SpeI, SspI, StuI, TaqI, XbaI and XhoI (New England Biolabs; Boehringer Mannheim). Eight of these enzymes (Aat II, Bam HI, KpnI, NcoI, Nhe I, PvuI, SacI,XhoI) did not digest the total DNA well and were not pursued. EcoRV digested the total DNA well but, as no bands were visible on the autoradiograph, was not pursued. Four enzymes resulted in differential digestion of the genomic and mtDNA. BglII, ClaI and HpaI digested the total DNA well but resulted in very high molecular weight smears on the autoradiograph, indicating that $L$. bonariensis mtDNA lacked recognition sites for these enzymes. StuI did not appear to digest the total DNA but did result in detected fragments. The remaining 12 enzymes (Asp700, EcoRI, HaeIII, HindIII, HinfI, MspI, PstI, Rsa I, Spe I, Ssp I, TaqI, $X b a \mathrm{I})$ digested the total DNA and resulted in bands being detected on the autoradiographs. Of these 12 enzymes, the following 10 were selected for further investigation: Eco RI, Hae III, HindIII, HinfI, Rsa I, Spe I, Ssp I, Stu I, TaqI and $X b a \mathrm{I}$.

Ten membranes were prepared by digesting DNA from one individual from each of $14 \mathrm{~L}$. bonariensis populations with each of these 10 enzymes. After probing with the entire boll weevil mitochondrial genome, no variation was detected between individuals with any of these 10 enzymes (not shown). Five enzymes (Eco RI, HindIII, HinfI, Rsa I and Spe I) were then selected to optimize the chance of detecting variation (Simon et al., 1993), on the basis that EcoRI, HindIII, RsaI and SpeI have recognition sites of at least 50 per cent $\mathrm{A}+\mathrm{T}$ and $R s a \mathrm{I}$ has a 4-bp recognition site.

\section{Mitochondrial results}

Two individuals from Brazil and four individuals from each of the remaining 14 populations were studied. Figure 1 gives examples of the restriction pattern generated by each of the enzymes in all 58 individuals. A single polymorphism was identified in one individual from Bariloche (absence of the 6403-bp fragment and presence of a 3142-bp fragment; Fig. 1e, Lane 9). All other patterns were identical, except that occasional fragments within digests were not detected. In three individuals from Bariloche the 4853-bp HindIII fragment was not detected (e.g. Fig. 1a, Lane 9). In one individual from Bariloche the 6403-bp SpeI fragment was not detected. There were also eight individuals (one each from Australia, Buenos Aires, Bahia Blanca, Bariloche, La Serena, Rio Negro, South Chile and Uruguay) in which the 8483-bp SpeI fragment was not detected. No data were generated with $R s a$ I for one individual each from Rio Negro, South Chile, Uruguay and Mendoza.

Mitochondrial genome size was estimated by summing the sizes of fragments generated by each enzyme. For the data presented here, four of the five restriction enzymes gave size estimates that were within 10 per cent of each other, which is an acceptable range given the methods of estimating fragment size. The sum of fragments generated by each of HindIII, Eco RI, HinfI and RsaI averaged $32862 \pm 2392$ bp (mean $\pm \mathrm{SD})$. For SpeI, the size estimate was $52819 \mathrm{bp}$, about $21 \mathrm{~kb}$ larger than the estimate from the other enzymes. With SpeI, all individuals generated a $21-\mathrm{kb}$ fragment. It is possible that this fragment is an incomplete digestion product, which would then bring the size estimate using this enzyme to 31359 bp (in line with the other four restriction enzymes). 

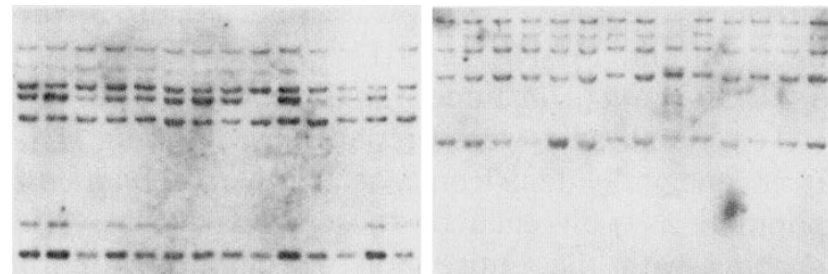

(a)

(b)
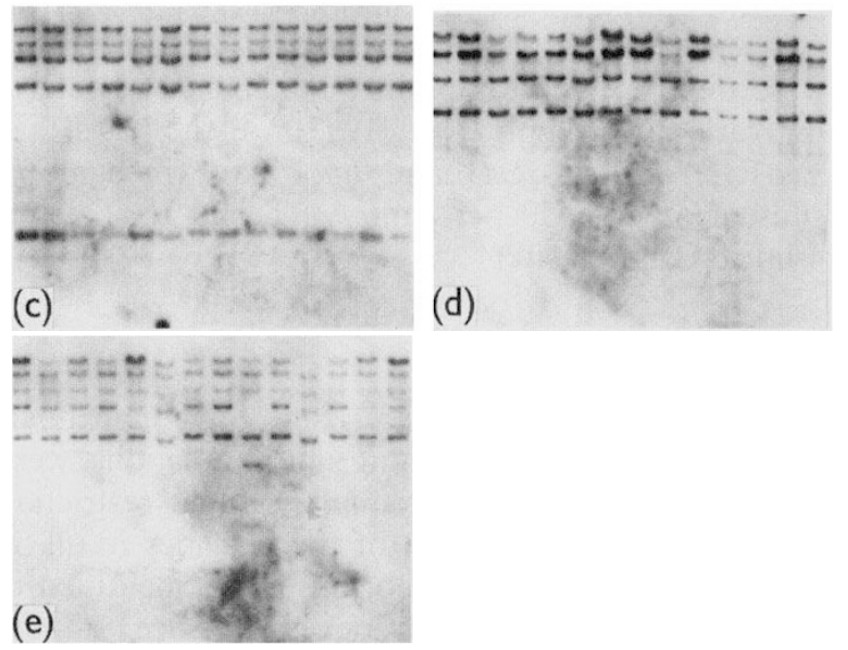

Fig. 1 Fragments detected by boll weevil mitochondrial DNA in Listronotus bonariensis DNA digested with (a) HindIII, (b) HinfI, (c) RsaI, (d) Eco RI and (e) SpeI. Each lane represents one individual from (1) Lincoln, (2) Wellsford, (3) Ruakura, (4) Reporoa, (5) Gore, (6) Australia, (7) Buenos Aires, (8) Bahia Blanca, (9) Bariloche, (10) La Serena, (11) Rio Negro, (12) South Chile, (13) Uruguay and (14) Mendoza. Fragment sizes are indicated on the left.

\section{Comparison with RAPD results}

To explore the possibility that mtDNA was amplified along with genomic DNA in our earlier study (Williams et al., 1994), RAPD products from individuals from several populations used previously were analysed on a 0.8 per cent agarose gel, then transferred onto a membrane and probed with the digoxigenin-labelled boll weevil mitochondrial probes (pBW21, pBW22, pBW23). No hybridization with mtDNA was detected among the RAPD products (results not shown).

\section{Discussion}

The results show an unusually large mitochondrial genome and the virtual absence of polymorphism.

Three individuals from Bariloche appeared to be 'missing' a fragment with HindIII (e.g. Fig. 1a, Lane 9). There were only a few similar instances, with
SpeI (not shown). These missing fragments could represent a deletion in the mitochondrial genome. If this were the case, the estimate of mitochondrial genome size should have been consistently smaller with all five restriction enzymes, which was not the case. For this reason, these 'missing' fragments were not deemed genuine polymorphisms. Incomplete transfer of DNA to the membrane and faulty hybridization could also account for these 'missing' fragments. Some membranes were stripped and reprobed, but only the original fragments were detected. Each weevil yielded only enough DNA for five digestions, so digests could not be repeated to verify results, as would have been possible with a larger organism. The 'missing' fragments did not assist in identifying a geographical source of $L$. bonariensis in New Zealand and were not pursued.

The size of the $L$. bonariensis mitochondrial genome is estimated to be $32 \mathrm{~kb}$. This size is acknowledged to be somewhat larger than expected, with typical mitochondrial genomes being of the order of 14-26 kb (Moritz et al., 1987). A mitochondrial genome of this size, however, is not unprecedented in Coleoptera. Boyce et al. (1989) reported mitochondrial genomes in bark weevils (Curculionidae: Pissodes) to be $30-36 \mathrm{~kb}$, resulting from an unusually large $(9-13 \mathrm{~kb}) \mathrm{A}+\mathrm{T}$-rich region. Subsequent attempts to amplify the $\mathrm{A}+\mathrm{T}$-rich region in L. bonariensis using a commercially available insect mitochondrial primer kit (University of British Columbia, Vancouver, BC, Canada; described in Simon et al., 1994) and standard PCR conditions were not successful, which would be consistent with an enlarged $\mathrm{A}+\mathrm{T}$-rich region (results not shown). It is possible that the large estimate of mitochondrial size may be the result of a larger $\mathrm{A}+\mathrm{T}$-rich region than is found in most species.

In addition to an unusually large mitochondrial genome size in bark weevils, Boyce et al. (1989) reported that all 219 individuals surveyed exhibited from two to five distinct size classes of mtDNA. Heteroplasmy in L. bonariensis could not be ruled out with the results presented here. First, all of the restriction enzymes used resulted in a size estimate that was somewhat larger than normal. It is possible that 100 per cent of the individuals studied were heteroplasmic for haplotypes which summed to 32 $\mathrm{kb}$. The presence of multiple haplotypes could lead to confusing, if not anomalous, banding patterns on autoradiographs. For example, if two haplotypes were present in an individual in unequal proportions, band intensities could vary considerably; such variation did occur occasionally in the results presented here. Heteroplasmy may also be respon- 
sible for the anomalous estimate of mitochondrial genome size with SpeI. It is possible that multiple haplotypes could generate identical restriction patterns with some enzymes but not others. For example, the Eco RI sites may be conserved between haplotypes, whereas the SpeI sites could be variable. Although this might not necessarily result in more fragments being detected using Spe I compared with EcoRI, it would result in a larger estimate of genome size with SpeI. If the individuals surveyed here were heteroplasmic, each must possess more than one haplotype, but the fact remains that these haplotypes did not vary to any extent within or among populations.

Only one genuine RFLP was noted, in DNA from one individual from Bariloche digested with SpeI (Fig. 1e, Lane 9). This RFLP could be a result of the addition of a cleavage site for this enzyme in the middle of the 6403-bp fragment common to all other individuals, because a 3142-bp fragment was detected in this individual. The slight mobility shifts in Fig. 1e (Lanes 6 and 11) in all the fragments generated in these individuals were not considered polymorphisms, because a corresponding shift was not seen with other enzymes. Because of the lack of variation, the mtDNA data were uninformative for determining the geographical origin of $L$. bonariensis in New Zealand.

The very low level of mtDNA variability found in this species suggests several possible scenarios. The first scenario is that further investigation with more enzyme/individual combinations could reveal polymorphisms. The design should have been strong enough, however, to detect variation. Initially 10 enzymes were screened, then 58 individuals were studied with five restriction enzymes (290 enzyme/ individual combinations), resulting in 26 fragments. The one RFLP noted was detected in only one individual out of 58 , which would be considered a rare haplotype by most standards. For these reasons, the low level of mtDNA variation detected is considered genuine, although unexpected, particularly in the native South American populations.

The next scenario is that the populations sampled in South America are only a subset of the species there and that further sampling would reveal greater mitochondrial diversity. Saunders et al. (1986) noted a major genetic 'break' between horseshoe crabs in Florida, with mtDNA diversity greater in the south than the north. As the authors pointed out, had their survey been restricted to the northern region they would have concluded that mitochondrial genetic diversity in this species was minimal. The sampled $L$. bonariensis populations covered a vast geographical range, however, so this scenario does not seem likely.

Low levels of mitochondrial variability alone could indicate the occurrence of a bottleneck in the history of the species (Wilson et al., 1985). For example, Drosophila simulans has a wide distribution and shows a very low level of mtDNA polymorphism within races, which is thought to result from a founder effect (Nigro, 1988; Baba-Aïssa et al., 1988). In its native habitat, $L$. bonariensis may have passed through a population bottleneck (perhaps caused by disease, predation or parasitism) which could have resulted in the decreased mitochondrial variability. Rapid range expansion (perhaps human-aided) following this bottleneck could explain the wide geographical occurrence of primarily a uniform mitochondrial haplotype.

To reconcile this hypothesis with the previous RAPD results (Williams et al., 1994) would require the assumption that the RAPD fragments are derived from regions of nuclear DNA with a higher evolutionary rate than the mtDNA, implying that the $L$. bonariensis populations in South America declined in size to such an extent that one (perhaps heteroplasmic) haplotype was present and that the species then expanded its geographical range. Following this range expansion, the genetic regions amplified by the RAPD primers apparently diverged, whereas the mitochondrial genome did not. The occurrence of high nuclear variability together with negligible mtDNA variability suggests that the $L$. bonariensis populations passed either through an ancient or a recent transient bottleneck (Wilson et al., 1985). Although this is not surprising for the colonized populations within New Zealand and Australia, it is an unexpected result with respect to the native $L$. bonariensis populations in South America.

Since the completion of this work, Lorenz et al. (1994) reported RAPD amplification products originating from both mitochondria and chloroplasts in total DNA preparations from sugar beet. Aagaard $e t$ al. (1995) also reported mtDNA contributing to RAPD amplification products in Douglas-fir. The possibility of organellar DNA contributing to RAPD amplification must be considered with every primer/ organism combination. Our results demonstrate that previously generated RAPD products did not originate from the mitochondrial genome and thus the RAPD and mitochondrial data are distinct data sets. Although the results obtained from the two techniques did not confirm each other, neither did they contradict one another. This dual result is consistent with other research, where different techniques have 
revealed different aspects of an organism's genetic structuring (Kambhampati \& Rai, 1991; LaTorre et al., 1992; Aagaard et al., 1995).

Grant \& Leslie (1993) pointed out that although mtDNA analysis has been touted as the ultimate tool for population studies (Wilson et al., 1985; Avise et al., 1987) its usefulness may not necessarily be universal. These authors noted that in the Northern Hemisphere mtDNA is more sensitive than nuclear markers to geographical differences between populations, whereas in southern Africa mtDNA variability is lower than nuclear variability. This difference was thought to be caused by the different population dynamics which occur in southern Africa, specifically the greater number of extinctions and recolonizations resulting from cycles of drought and rainfall. Through computer simulations that incorporated population growth and migration, extinction and recolonization, Grant \& Leslie (1993) demonstrated that variability in organellar DNA in large mammals declined much more rapidly than variability in nuclear DNA.

The observation that cycles of population extinction, recolonization and expansion can lead to a loss of organellar DNA variability, but may not be severe enough to lead to loss of nuclear variability, may apply equally well to other species, including insects. Such cycles of growth and decline in population size perhaps offer a more realistic explanation for the difference in variability between nuclear and mtDNA in $L$. bonariensis than the bottlenecking described by Wilson et al. (1985), although both hypotheses depend on subsequent range expansion given the vast distances associated with the native habitat of the species.

\section{Acknowledgements}

We are grateful to Richard Roerhdanz for generously providing the boll weevil mitochondrial clones. This research was funded from a grant to the New Zealand Pastoral Agricultural Research Institute, Ltd. by the New Zealand Foundation for Research, Science and Technology.

\section{References}

AAGAARD, J. E., VOLLMER, S. S., SORENSON, F. C. AND strauss, S. H. 1995. Mitochondrial DNA products among RAPD profiles are frequent and strongly differentiated between races of Douglas-fir. Mol. Ecol., 4, 441-447.

AVISE, J. C., ARNOLD, J., BALL, R. M., BERMINGHAM, E., LAMB, T., NElGEL, J. E. ET AL. 1987. Intraspecific phylo- geography: the mitochondrial DNA bridge between population genetics and systematics. Ann. Rev. Ecol. Syst., 18, 489-522.

BABA-AíSSA, F., SOLIGNAC, M., DENNEBOUY, N. AND DAVID, J. R. 1988. Mitochondrial DNA variability in Drosophila simulans: quasi absence of polymorphism within each of three cytoplasmic races. Heredity, 61, 419-426.

BOEHRINGER-MANNHEIM. 1993. The DIG System User's Guide for Filter Hybridization. Boehringer Mannheim GmbH Biochemica, Mannheim.

BOYCE, T. M., ZWICK, M. E. AND AQUADRO, C. F. 1989. Mitochondrial DNA in the bark weevils: size, structure and heteroplasmy. Genetics, 123, 825-836.

BROWN, J. R., BECKENBACH, A. T. AND SMITH, M. J. 1992. Mitochondrial DNA length variation and heteroplasmy in populations of white sturgeon (Acipenser transmontanus). Genetics, 132, 221-228.

CHAPCO, w., KELLN, R. A. AND McFADYEN, D. A. 1992. Intraspecific mitochondrial DNA variation in the migratory grasshopper, Melanoplus sanguinipes. Heredity, 69 , 547-557.

CLARY, D. O. AND WOLSTENHOLME, D. R. 1985. The mitochondrial DNA molecule of Drosophila yakuba: Nucleotide sequence, gene organization, and genetic code. $J$. Mol. Evol., 22, 252-271.

GOLDSON, S. L. AND EMBERSON, R. M. 1980. Relict diapause in an introduced weevil in New Zealand. Nature, 286, 489-490.

GRANT, w. S. AND LESLIE, R. W. 1993. Effect of metapopulation structure on nuclear and organellar DNA variability in semi-arid environments of southern Africa. S. Af. J. Sci., 89, 287-293.

GYLLENSTEN, U., WHARTON, D., JOSEFSSON, A. AND WILSON, A. C. 1991. Paternal inheritance of mitochondrial DNA in mice. Nature, 352, 255-257.

HOEH, W. R., BLAKLEY, K. H. AND BROWN, W. M. 1991. Heteroplasmy suggests limited biparental inheritance of Mytilus mitochondrial DNA. Science, 251, 1488-1490.

KAMBHAMPAT1, S. AND RA1, K. 1991. Mitochondrial DNA variation within and among populations of the mosquito Aedes albopictus. Genome, 34, 288-292.

KONDO, R., SATTA, Y., MATSUURA, E. T., ISHIWA, H., TAKAHATA, N. AND CHIGUSA, S. I. 1990. Incomplete maternal transmission of mitochondrial DNA in Drosophila. Genetics, 126, 657-663.

LANSMAN, R. A., AVISE, J. C., AQuARDo, C. F., ShapiRA, J. F. AND DANIEL, S. W. 1983. Extensive genetic variation in mitochondrial DNAs among geographic populations of the deer mouse, Peromyscus maniculatus. Evolution, 37, $1-16$.

LATORRE, A., HERNÁNDEZ, C., MARTínez, D., CASTRO, J. A., RAMÓN, M. AND MOYA, A. 1992. Population structure and mitochondrial DNA gene flow in Old World populations of Drosophila subobscura. Heredity, 68, 15-24.

LORENZ, M., WEIHE, A. AND BÖRNER, T. 1994. DNA fragments of organellar origin in random amplified polymorphic DNA (RAPD) patterns of sugar beet (Beta vulgaris L.). Theor. Appl. Genet., 88, 775-779.

MORITZ, C., DOWLING, T. E. AND BROWN, w. M. 1987. Evolu- 
tion of animal mitochondrial DNA: relevance for population biology and systematics. Ann. Rev. Ecol. Syst., 18, 269-292.

NIGRo, L. 1988. Natural populations of Drosophila simulans show great uniformity of the mitochondrial DNA restriction map. Genetica, 77, 133-136.

O'RYAN, C. AND HARLEY, E. H. 1993. Comparisons of mitochondrial DNA in black and white rhinoceroses. $J$. Mammal., 74, 343-346.

PRESTIDGE, R. A., BARKER, G. M. AND POTTINGER, R. P. 1991. The economic cost of Argentine stem weevil in pastures in New Zealand. Proc. 44th New Zealand Weed and Pest Control Conference, pp. 165-170.

RAND, D. M. AND HARRISON, R. G. 1989. Molecular population genetics of mtDNA size variation in crickets. Genetics, 121, 551-569.

ROEHRDANZ, R. L. 1989. Intraspecific genetic variability in mitochondrial DNA of the screwworm fly (Cochliomyia hominivorax). Biochem. Genet., 27, 551-569.

ROEHRDANZ, R. L. AND JOHNSON, D. A. 1988. Mitochondrial DNA variation among geographical populations of the screwworm fly, Cochliomyia hominivorax. J. Med. Entomol., 25, 136-141.

ROEHRDANZ, R. L. AND NORTH, D. L. 1992. Mitochondrial DNA restriction fragment variation and biosystematics of the boll weevil, Anthonomus grandis. Southwestern Entomologist, 17, 101-108.

SAMBROOK, J., FRITSCH, E. F. AND MANIATIS, T. 1989. Molecular Cloning: A Laboratory Manual, 2nd edn. Cold Spring Harbor Laboratory Press, Cold Spring Harbor, NY.

SAUNDERS, N. C., KESSLER, L. G. AND AVISE., J. C. 1986. Genetic variation and geographic differentiation in mitochondrial DNA of the horseshoe crab, Limulus polyphemus. Genetics, 112, 613-627.

SCHAFFER, H. E. AND SEDEROFF, R. R. 1981. Improved estimation of DNA fragment lengths from agarose gels. Analyt. Biochem., 115, 113-122.

SHEPPARD, W. S., STECK, G. J. AND MCPHERON, B. A. 1992. Geographic populations of the medfly may be differentiated by mitochondrial DNA variation. Experientia, 48, 1010-1013.

SimON, C., Mcintosh C. AND DENIEGA, J. 1993. Standard restriction fragment length analysis of the mitochondrial genome is not sensitive enough for phylogenetic analysis or identification of 17 -year periodical cicada broods: the potential for a new technique. Ann. Entomol. Soc. Am., 86, 228-238.

SIMON, C., FRATI, F., BECKENBACH, A., CRESPI, B., LIU, H. AND FLOOK, P. 1994. Evolution, weighting, and phylogenetic utility of mitochondrial gene sequences and a compilation of conserved polymerase chain reaction primers. Ann. Entomol. Soc. Am., 87, 651-701.

SKIBINSKI, D. O. F., GALLAGHER, C. AND BEYNON, C. M. 1994. Sex-limited mitochondrial DNA transmission in the marine mussel Mytilus edulis. Genetics, 138, 801-809.

TORRINI, A., SCHURR, T. G., YANG, C.-C., SZATHMARY, E. J. E., Williams, R. C., SCHANFIElD, M. S. ET AL. 1992. Native American mitochondrial DNA analysis indicates that the Amerind and the Nadene populations were founded by two independent migrations. Genetics, 130, $153-162$.

WALDMAN, J. R. AND WIRGIN, I. I. 1994. Origin of the present Delaware River striped bass population as shown by analysis of mitochondrial DNA. Trans. Am. Fish. Soc., 123, 15-21.

WAYNE, R. K., GEORGE, S. B., GILBERT, D., COLlins, P. W., KOVACH, S. D., GIRMAN, D. AND LEHMAN, N. 1991. A morphologic and genetic study of the island fox, Urcoyon littoralis. Evolution, 45, 1849-1868.

WELSH, J. AND MCCLELlAND, M. 1990. Fingerprinting genomes using PCR with arbitrary primers. Nucl. Acids Res., 18, 7213-7218.

WILLIAMS, C. L., GOLDSON, S. L., BAIRD, D. B. AND BULLOCK, D. w. 1994. Geographical origin of an introduced insect pest, Listronotus bonariensis (Kuschel), determined by RAPD analysis. Heredity, 72, 412-419.

WILLIAMS, J. G. K., KUBELIK, A. R., LIVAK, K. J., RAFALSKI, J. A. AND TINGEY, s. v. 1990. DNA polymorphisms amplified by arbitrary primers are useful as genetic markers. Nucl. Acids Res., 18, 6531-6535.

WILSON, A. C., CANN, R. L., CARR, S. M., GEORGE, M., GYLLENSTEN, U. B., HELM-BYCHOWSKI, K. M. ET AL. 1985. Mitochondrial DNA and two perspectives on evolutionary genetics. Biol. J. Linn. Soc., 26, 375-400. 